\title{
EFEKTIVITAS MEDIASI DALAM PENANGANAN PERCERAIAN DI PENGADILAN AGAMA PONOROGO
}

\author{
Yulia Aswaty ${ }^{1^{*}}$ Martha Eri Safira ${ }^{2 *}$ \\ 1,2 Fakultas Syariah, IAIN Ponorogo \\ 1Email: yuliamihardjo19@gmail.com \\ 2Email: martha@iainponorogo.ac.id
}

\begin{tabular}{l|l|l}
\hline \multicolumn{3}{l}{ DOI: } \\
\hline Received: $31-7-2021$ & Revised: $15-8-2021$ & Approved: $30-8-2021$ \\
\hline
\end{tabular}

Abstract: Every civil case in court must be resolved through mediation first. As technology develops, PERMA No. 1 of 2016 concerning mediation provides an option for parties who cannot attend in-person to carry out audio-visual mediation. The purpose of this study was to find out how the implementation and effectiveness of direct and audio-visual mediation in the settlement of divorce cases in PA Ponorogo and what factors were supporting and inhibiting its effectiveness. This is an empirical study that employs a qualitative approach. data collection techniques use observation, interviews, and documentation, while the analysis uses inductive analysis. From this study, it was concluded that in divorce cases in PA Ponorogo, direct mediation was more effective than audio-visual. Factors supporting the effectiveness of direct mediation are the ability of a mediator and a reliable legal representative; the existence of legal awareness; the existence of good faith; and the existence of legal knowledge of the parties. Then there are the supporting factors of audio-visual mediation, which are adequate facilities, informative and educative communication of attorneys to their clients, good faith and legal knowledge of the parties, and the agreed schedule. While the inhibiting factors of the two mediation models are the panel of judges' policies, inadequate facilities, time zone differences, and the emotions of the parties.

Keyword: Effectiveness, Mediation, Ponorogo, Religious Courts.

Abstrak: Setiap perkara perdata di pengadilan harus diselesaikan melalui mediasi terlebih dahulu. Seiring berkembangnya teknologi, PERMA No. 1 Tahun 2016 tentang mediasi memberikan opsi bagi pihak yang tidak dapat hadir secara langsung dapat melaksanakan mediasi secara audio visual. Tujuan dari penelitian ini untuk mengetahui bagaimana implementasi dan efektivitas antara mediasi secara langsung dan secara audio visual dalam penyelesaian perkara cerai di PA Ponorogo serta apa saja faktor pendukung dan penghambat efektivitasnya. Penelitian ini merupakan penelitian yuridis empiris dengan menggunakan pendekatan kualitatif. Untuk teknik pengumpulan data menggunakan observasi, wawancara dan dokumentasi, sedangkan analisisnya menggunakan analisis induktif. Dari penelitian ini disimpulkan bahwa dalam perkara cerai di PA Ponorogo, mediasi secara langsung lebih efektif daripada secara audio visual. Faktor pendukung efektivitas mediasi secara langsung adalah; kemampuan mediator dan kuasa hukum yang andal, adanya kesadaran hukum, adanya iktikad 
baik, dan adanya pengetahuan hukum para pihak. Kemudian faktor pendukung mediasi audio visual yakni; fasilitas yang memadai, komunikasi kuasa hukum pada kliennya yang informatif dan edukatif, iktikad baik dan pengetahuan hukum para pihak yang baik serta jadwal yang disepakati. Sedangkan faktor penghambat dari model mediasi keduanya adalah kebijakan majelis hakim, fasilitas yang kurang memadai, perbedaan zona waktu, dan emosional para pihak.

Kata Kunci: Efektivitas, Mediasi, Pengadilan Agama, Ponorogo.

\section{PENDAHULUAN}

Secara etimologi, mediasi berasal dari bahasa latin mediare yang berarti berada di tengah. Makna ini menunjuk pada peran yang ditampilkan pihak ketiga sebagai mediator dalam menjalankan tugasnya menengahi dan menyelesaikan sengketa di antara pihak-pihak yang bersengketa. ${ }^{1}$ Sedangkan dalam ajaran Islam dikenal dengan istilah islah. Islah adalah memutuskan suatu persengketaan, sedangkan menurut istilah syarakat islah adalah suatu akad dengan maksud mengakhiri suatu persengketaan antara dua orang. ${ }^{2}$ Sebagai metode penyelesaian sengketa secara damai, mediasi mempunyai peluang yang besar untuk berkembang di Indonesia. Menyelamatkan muka (Face saving) atau nama baik seseorang adalah hal penting yang lebih diutamkan dalam proses penyelesaian sengketa di negara berbudaya timur termasuk Indonesia. ${ }^{3}$

Dalam sistem hukum Indonesia ada beberapa alternatif penyelesaian sengketa di luar peradilan yang didasarkan pada UU No. 30 Tahun 1999 Tentang Alternatif Penyelesaian Sengketa antara lain; konsultasi, negoisasi dan perdamaian, mediasi, konsiliasi dan perdamaian, pendapat hukum oleh lembaga arbitrase, dan arbitrase. Dari beberapa alternatif tersebut, mediasi merupakan alternatif terbaik mengingat upaya perdamaian sebagai suatu langkah awal dalam perkara perdata yang diajukan di satu pengadilan tingkat pertama merupakan tahapan yang efektif dan efisien untuk menciptakan kondisi win-win solution. ${ }^{4}$ W.E

\footnotetext{
1 Syahrizal, Agustina Arida, dan Luthfi Aunie, Mediasi dalam perspektif hukum syariah, hukum adat \& hukum nasional, Cet. 1 (Jakarta: Kerja sama Canadian International Development Agency ... [et al.], 2009), 2.

2 Yayah Yarotul Salamah, "Urgensi Mediasi dalam Perkara Perceraian di Pengadilan Agama," AHKAM : Jurnal Ilmu Syariah 13, no. 1 (1 Februari 2013): 81, https://doi.org/10.15408/ajis.v13i1.953.

${ }^{3}$ Fatahillah A. Syukur, Mediasi Yudisial Di Indonesia (Bandung: Mandar Maju, 2012), 4.

4 Netty Herawati, "Implikasi Mediasi Dalam Perkara Perdata Di Pengadilan Negeri Terhadap Asas Peradilan Sederhana, Cepat, Dan Biaya Ringan," Perspektif 16, no. 4 (27 September 2011): 228, https://doi.org/10.30742/perspektif.v16i4.85.
} 
Burger pernah menyatakan bahwa tidak benar kebanyakan orang menginginkan hakim berjubah hitam, advokat berpakaian bagus, dan ruang siding berpanel bagus dalam menyelesaikan perselisihan mereka. Orang bermasalah adalah seperti orang sedang kesakitan. Mereka menginginkan pertolongan dan mereka menginginkannya secepat dan semurah mungkin. ${ }^{5}$

Melalui Peraturan Mahkamah Agung (PERMA) No. 2 Tahun 2003 yang kemudian diperbarui menjadi PERMA No. 1 Tahun 2008, kemudian diubah lagi menjadi PERMA No.1 Tahun 2016 Tentang Prosedur Mediasi di Pengadilan, mediasi telah diintegrasikan dalam sistem beracara di pengadilan. Setiap perkara perdata harus diselesaikan terlebih dahulu melalui cara mediasi. Setiap putusan hakim yang tidak melalui cara mediasi terlebih dahulu, maka putusan dianggap batal demi hukum. ${ }^{6}$ Salah satu perkara yang membutuhkan mediasi adalah perkara perceraian. Bagi umat Muslim, perceraian dilakukan di Pengadilan Agama (selanjutnya disingkat PA). Hal ini sesuai dengan penjelasan pada Pasal 49 UU No. 3 Tahun 2006 Tentang Peradilan Agama. Dalam sidang pertama perkara perceraian, ketika kedua belah pihak yang berperkara hadir di persidangan, maka hakim mewajibkan kedua belah pihak untuk melaksanakan mediasi, kemudian berunding untuk memilih mediator untuk melaksanakan proses mediasi yang aturannya juga terdapat pada PERMA No. 1 Tahun 2016 Tentang Prosedur Mediasi di Pengadilan.

PA Ponorogo adalah lembaga peradilan yang dalam kinerjanya juga sesuai dengan peraturan yang berlaku, salah satunya adalah dalam proses mediasi. Perkara perceraian yang terdaftar di PA Ponorogo dari bulan Januari sampai dengan Desember tahun 2020 sebanyak 1.910 perkara. Dengan total cerai gugat sebanyak 1.412 perkara dan cerai talak sebanyak 498 perkara. ${ }^{7}$ Namun hanya

5 Muhammad Faiz Aziz dan Muhamamd Arif Hidayah, "Perlunya Pengaturan Khusus Online Dispute Resolution (Odr) Di Indonesia Untuk Fasilitasi Penyelesaian Sengketa E-Commerce," Jurnal Rechts Vinding: Media Pembinaan Hukum Nasional 9, no. 2 (27 Agustus 2020): 279, https://doi.org/10.33331/rechtsvinding.v9i2.449.

6 Muhammad Saifullah, "Efektivitas Mediasi Dalam Penyelesaian Perkara Perceraian Di Pengadilan Agama Jawa Tengah,” Al-Ahkam 25, no. 2 (24 Oktober 2015): 181, https://doi.org/10.21580/ahkam.2015.25.2.601.

${ }^{7}$ Laporan Perkara yang diterima Pengadilan Agama Ponorogo Bulan Januari s/d Desember Tahun 2020 
sebanyak 1.769 perkara cerai yang sampai di putus, yakni cerai gugat sebanyak 1.320 perkara, sedangkan cerai talak sebanyak 449 perkara. ${ }^{8}$

Menarik ke belakang yakni pada tahun 2017, upaya perdamaian (mediasi) yang dilakukan oleh pihak PA Ponorogo hampir 99\% tidak berhasil. Rendahnya keberhasilan mediasi dalam perkara cerai gugat dikarenakan tidak hadirnya Penggugat yang dalam hal tersebut diwakilkan oleh pengacaranya. Namun terhadap hal tersebut, mediator keberatan apabila salah satu pihak tidak hadir dan diwakilkan pengacaranya. Ketakutan akan kebohongan dalam menjalankan proses mediasi dikarenakan mediator tidak bertemu langsung dengan yang bersangkutan. ${ }^{9}$

Semakin berkembangnya teknologi yang ada pada saat ini, seseorang yang berjarak jauh sudah bisa saling berkomunikasi dengan teknologi internet dan smartphone yang memiliki beragam fitur komunikasi. PERMA No. 1 Tahun 2016 Tentang Prosedur Mediasi di Pengadilan memberikan keringanan bagi seseorang yang tidak dapat hadir dalam proses mediasi. Dalam PERMA No. 1 Tahun 2016 diatur bahwa mediasi dapat dilakukan secara langsung dan secara audio visual ${ }^{10}$. Hal ini sebagai mana tertuang dalam ketentuan Pasal 5 PERMA No. 1 Tahun 2016 yang berbunyi sebagai berikut; ${ }^{11}$ 1) Proses mediasi pada dasarya bersifat tertutup kecuali para pihak menghendaki lain; 2) Penyampaian laporan mediator mengenai pihak yang beriktikad baik dan ketidak berhasilan proses mediasi kepada hakim pemeriksa perkara bukan merupakan pelanggaran bersifat tertutup; 3) Pertemuan mediasi dapat dilakukan melalui media komunikasi audio visual jarak jauh yang memungkinkan semua pihak saling melihat dan mendengar secara langsung serta berpartisipasi dalam pertemuan.

Pada ayat (3) tersebut menjelaskan bahwa diperbolehkan mediasi melalui audio visual bagi prisipiel yang tidak hadir dalam acara mediasi yang dikarenakan jarak yang tidak memungkinkan untuk hadir di PA. Dari 1.910 perkara yang masuk

8 Laporan Perkara yang diputus Pengadilan Agama Ponorogo Bulan Januari s/d Desember Tahun 2020

9 Rohana Muawwanah, "Realitas Gugat Cerai TKW (Asia Timur) di Kabupaten Ponorogo: Sebuah Tinjauan Hukum Islam," Edugama: Jurnal Kependidikan dan Sosial Keagamaan 5, no. 2 (1 Desember 2019): 168, https://doi.org/10.32923/edugama.v5i2.975.

10 Audio Visual di artikan sebagai media yang memiliki unsur gambar dan unsur suara. Jenis media ini cenderung memiliki kualitas yang lebih baik, karena melibatkan dua unsur yang saling melengkapi. Unsur tersebut yakni unsur visual (melihat) dan unsur auditif (mendengar).

11 Pasal 5 PERMA RI No.1 Tahun 2016 Tentang Prosedur Mediasi di Pengadilan. 
terkait perceraian (bulan Januari-Desember 2020)12, pelaksanaan mediasi secara langsung sejumlah $97 \%$ dan mediasi secara audio visual sejumlah 3\% dari total 269 mediasi perkara cerai. ${ }^{13}$

Terdapat banyak penelitian yang membahas mediasi, baik dari segi teori dan prakteknya di berbagai tempat. Sebut saja misalnya penelitian yang dilakukan oleh Putri Nafisah, ${ }^{14}$ tentang "Implemetasi Mediasi Melalui Sarana Audio Visual Berdasarkan PERMA No. 1 Tahun 2016 Pasal 5 ayat (3)”. Penelitian lainnya dilakukan Tsaniah Rochmat Kamardeka Mas,15 tentang "Proses Mediasi Di Pengadilan Agama Karanganyar Dalam Penyelesaian Perkara Perceraian Ditinjau Dari Perma No. 1 Tahun 2016". Berikutnya penelitian yang dilakukan Muhammad Chanafi,16 "Evektifitas Peran Hakim Sebagai Mediator Dalam Upaya Penyelesaian Sengketa Melalui Mediasi Di Pegadilan Agama Karanganyar Tahun 2015-2017”.

Dari beberapa telaah terdahap penelitian tersebut, keseluruhan hanya fokus pada aspek mediasi secara umum dan belum ada yang secara spesifik melakukan perbandingan pelaksanaan mediasi secara langsung dan secara audio visual. Aspek inilah yang membuat penelitian ini berbeda. Terlebih seiring berkembangnya teknologi segala hal bukan sangat tidak mungkin dapat dilakukan secara daring. Dengan demikian, penelitian ini akan difokuskan pada pertanyaan terkait bagaimana implementasi mediasi secara langsung dan secara audio visual dalam penyelesaian perkara cerai dan apa faktor pendukung dan penghambat efektivitas pelaksanaan mediasi secara langsung dan secara audio visual dalam penyelesaian perkara cerai di Pengadilan Agama Ponorogo?

Penelitian ini merupakan penelitian hukum empiris (yuridis empiris). Penelitian hukum empiris merupakan penelitian hukum yang dimaksudkan untuk mengkaji dan menganalisis bekerjanya hukum di dalam masyarakat, yang 2020

12 Laporan Perkara yang diterima Pengadilan Agama Ponorogo Bulan Januari s/d Desember Tahun

13 Data Statistik Perkara Yang Di Mediasi Di Pengadilan Agama Ponorogo Bulan Januari s/d Desember Tahun 2020.

14 Putri Nafisah, "Implemetasi Mediasi Melalui Sarana Audio Visual Berdasarkan PERMA No. 1 Tahun 2016 Pasal 5 ayat (3)”, (Skripsi, Universitas Islam Negeri Maulana Malik Ibrahim Malang, 2018).

15 Tsaniah Rochmat Kamardeka Mas, "Diajukan Kepada Fakultas Syariah Institut Agama Islam Negeri (IAIN) Surakarta Untuk Memenuhi Sebagian Persyaratan Guna Memperoleh Gelar Sarjana Hukum," no. 1 (2016): 127.

${ }_{16}$ Muhammad Chanafi, "Disusun dan Diajukan Untuk Melengkapi Tugas-tugas dan Syarat-syarat Guna Mencapai Derajat Sarjana Hukum pada Fakultas Hukum Universitas Muhammadiyah Surakarta,” t.t., 12. 
termanifestasi ke dalam perilaku hukum masyarakat. ${ }^{17}$ Selain itu jenis penelitian ini adalah penelitian lapangan (field research), karena penelitian ini dilaksanakan di lingkungan tertentu, yakni di lingkup PA Ponorogo. Penelitian ini menggunakan pendekatan kualitatif, karena data-data yang dibutuhkan bisa didapatkan dengan akurat dan mengena pada titik permasalahan yang diteliti dalam hal pelaksanaan mediasi secara langsung dan secara audio visual dalam perkara cerai di PA Ponorogo.

\section{MEDIASI DI PENGADILAN AGAMA DAN EFEKTIVITAS HUKUM}

Dalam Pasal 1 Angka 6 PERMA No. 2 Tahun 2003, mediasi didefinisikan sebagai penyelesaian sengketa melalui proses perundingan para pihak dengan dibantu oleh mediator. Sedangkan pengertian mediasi dalam PERMA No. 1 Tahun 2008 diatur dalam Pasal 1 Angka 7 dan semakna dengan pengertian mediasi yang diatur dalam Pasal 1 Angka 1 PERMA No. 1 Tahun 2016, mediasi adalah cara penyelesaian sengketa melalui proses perundingan untuk memperoleh kesepakatan para pihak dengan dibantu oleh mediator. ${ }^{18}$ Sedangkan pengertian mediator sendiri menurut PERMA No. 1 tahun 2016, Mediator adalah Hakim atau pihak lain yang memiliki Sertifikat Mediator sebagai pihak netral yang membantu Para Pihak dalam proses perundingan guna mencari berbagai kemungkinan penyelesaian sengketa tanpa menggunakan cara memutus atau memaksakan sebuah penyelesaian.

Dasar hukum yang melandasi penerapan mediasi dalam hukum positif di Indonesia terdapat dalam beberapa peraturan dan Undang-Undang, di antaranya; ${ }^{19}$

1) Pasal 130 HIR, R.Bg atau Pasal 31 Rv.

2) UU No. 30 Tahun 1999 tentang Arbitrase dan Alternatif Penyelesaian Sengketa (APS).

3) PERMA RI No. 2 Tahun 2003 tentang Prosedur Mediasi Di Pengadilan.

4) PERMA RI No. 1 Tahun 2008 tentang Prosedur Mediasi Di Pengadilan.

5) PERMA RI No. 1 Tahun 2016 tentang Prosedur Mediasi Di Pengadilan.

17 Ubaid Al Faruq, “Metode Penelitian Hukum,” t.t., 62.

18 Pasal 1 Ayat (2) PERMA RI No.1 Tahun 2016 Tentang Prosedur Mediasi di Pengadilan.

19 Wirhanuddin, "Deskripsi Tentang Mediasi Di Pengadilan Tinggi Agama Makassar: Perspektif Hukum Islam", Al-Fikr, Vol. 20 No.2 (2015), 286. 
6) SEMA RI No. 1 Tahun 2002 tentang Pemberdayaan Lembaga Perdamaian dalam Pasal 130 HIR/Pasal 154 RBg.

Sedangkan dasar hukum mediasi dalam hukum Islam terdapat dalam AlQur'an Surat Al-Hujurat ayat 9-10, Al-Qur'an Surat an-Nisa' ayat 114, dan Al-Qur'an Surat an-Nisa' ayat $114 .^{20}$

Pada tiap tahapan pemeriksaan perkara di pengadilan, hakim pemeriksa perkara tetap berwenang untuk mengusahakan perdamaian hingga sebelum pengucapan putusan. Jika mediasi gagal, pernyataan dan pengakuan para pihak dalam proses mediasi tidak dapat digunakan sebagai alat bukti dalam proses persidangan. ${ }^{21}$ Ketika proses mediasi yang dilakukan dengan menghadirkan pihak ketiga mediator berada dalam salah satu keadaan tersebut, maka mediasi bisa dikatakan telah berakhir. Artinya tidak tercapai kesepakatan tertulis menjadi bukti berhasil atau tidak berhasilnya proses mediasi. ${ }^{22}$

Sedangkan efektivitas hukum menurut Soerjono Soekanto adalah bahwa efektivitas suatu tertib hukum dan efektivitas suatu kaidah hukum tertentu merupakan suatu kondisi bagi sahnya kaidah hukum. Efektivitas merupakan suatu kondisi dalam arti bahwa tertib hukum atau kaidah hukum tertentu tak dapat dianggap sah lagi apabila efektivitasnya hilang atau pudar. ${ }^{23}$

Menurut Soerjono Soekanto efektif atau tidaknya suatu hukum ditentukan oleh 5 (empat) faktor, yaitu: ${ }^{24}$

a. Kaidah hukum atau peraturan itu sendiri (Undang-Undang)

b. Petugas yang menegakan atau menerapkan

c. Fasilitas yang diharapkan akan dapat mendukung pelaksanaan kaidah hukum

d. Warga masyarakat yang terkena ruang lingkup peraturan tersebut

e. Budaya Hukum, yakni sebagai hasil karya, cipta dan rasa yang didasarkan pada karsa manusia di dalam pergaulan hidup

20 Susanti Adi Nugroho, Mediasi Sebagai Alternatif Penyelesaian Sengketa, (Jakarta: PT. Telaga Ilmu Indonesia, 2009), 166.

21 Pasal 32 PERMA RI No.1 Tahun 2016 Tentang Prosedur Mediasi di Pengadilan.

22 Endrik Safudin, Alternatif penyelesaian sengketa dan arbitrase, Cetakan pertama (Malang: Intrans Publishing, 2018), 57.

23 Soerjono Soekanto, Penegakan hukum, (Bandung: Bina cipta, 1983), 26.

24 Soerjono Soekanto, Faktor-Faktor Yang Mempengaruhi Penegakan Hukum, (Depok: RajaGrafindo Persada, 2018), 11. 
Kelima faktor di atas sangat berkaitan dengan eratnya, oleh karena merupakan esensi dari penegakan hukum, juga merupakan tolak ukur dari pada efektivitas penegakan hukum.

\section{EFEKTIVITAS MEDIASI SECARA LANGSUNG DAN SECARA AUDIO VISUAL DALAM PENYELESAIAN PERKARA CERAI DI PENGADILAN AGAMA PONOROGO}

Dalam pelaksanaan mediasi, PA Ponorogo telah melakukan dua macam mediasi, yakni mediasi secara langsung dan mediasi secara jarak jauh (virtual) dengan perantara media audio visual. ${ }^{25}$ PA ponorogo lebih banyak melaksanakan mediasi secara langsung ketimbang mediasi secara audio visual. Dari 269 perkara cerai yang di mediasi di PA Ponorogo bulan Januari-Desember 2020, mediasi secara langsung sejumlah 260 perkara cerai, jadi 97\% mediasi perkara cerai di PA Ponorogo dilakukan secara langsung. ${ }^{26} \mathrm{Hal}$ ini karena mediasi secara audio visual hanya bersifat darurat/ tidak bisa menjadi patokan umum. ${ }^{27}$ Sedangkan untuk keberhasilan mediasi secara langsung, dari 260 mediasi cerai secara langsung, 9 perkara berhasil dengan pencabutan, dan 251 perkara tidak berhasil. ${ }^{28}$

Kewajiban menghadiri mediasi bagi para pihak juga merupakan tujuan dari pelaksanaan mediasi, yakni agar para pihak dapat berkomunikasi secara langsung, berhadap-hadapan, berdiskusi, dan berbicara supaya ada sambung rasa antar para pihak tersebut. Tak hanya itu, komunikasi antara para pihak secara langsung di harap dapat membawa rasa empati yang dapat ditangkap oleh masing-masing pihak yang berperkara. ${ }^{29}$ Mediasi secara langsung ini dilakukan secara bersamasama antar para pihak yang berperkara, kuasa hukumnya, dan juga mediator dalam satu tempat untuk berunding dengan tujuan mencapai sebuah perdamaian. Mediasi dilaksanakan di ruang mediasi/ ruang kaukus PA Ponorogo. ${ }^{30}$

Hal ini sebagaimana diungkapkan mediator PA Ponorogo sebagai berikut;

"Kalau fokus diperkara perceraian, standar pelaksanaan mediasi minimal dua kali. Tetapi jika memang dalam posisi tertentu semisal perkara waris, hadanah, atau yang lain, di mana dalam posisi ketika mediasi pertama

25 Ahmad Ubaidillah, Hasil Wawancara, Ponorogo, 22 Desember 2020.

26 Data Statistik Perkara Yang Di Mediasi Di Pengadilan Agama Ponorogo Bulan Januari s/d Desember Tahun 2020.

27 Ahmad Ubaidillah, Hasil Wawancara, Ponorogo, 22 Desember 2020.

28 Data Statistik Perkara Yang Di Mediasi Di Pengadilan Agama Ponorogo Bulan Januari s/d Desember Tahun 2020

${ }^{29}$ Ahmad Ubaidillah, Hasil Wawancara, Ponorogo, 22 Desember 2020.

30 Ibid. 
para pihak menyepakati satu dan lain hal namun tidak bisa diputuskan pada waktu itu, maka kemungkinan besar para pihak itu memilih untuk mengambil jeda waktu. Tetapi dalam konteks ini juga harus berpatokan pada batas waktu yang sudah ada sesuai dengan PERMA RI No. 1 Tahun 2016 Tentang Prosedur Mediasi di Pengadilan."31

Namun ternyata ada keterangan lain terkait pelaksanaannya di lapangan yakni dalam hukum acara, mediasi dilakukan sepanjang diperlukan dengan jangka waktu mediasi 30 hari dari penetapan hari mediasi dengan minimal dilakukan sebanyak dua kali mediasi dengan catatan kedua belah pihak sama-sama hadir. Tapi, banyak pengadilan yang tanda tangan mediasinya 2 kali padahal pelaksanaanya hanya sekali termasuk di PA Ponorogo. ${ }^{32}$

"Banyak pengadilan yang tanda tangan mediasinya 2 kali padahal pelaksanaanya hanya sekali, itu hanya untuk memenuhi pembukuan mediator. Sesuai dengan aturan memang 2 kali minimal, tapi kadang ada juga dalam perceraian kalau prinsipiel $\mathrm{P}$ dan $\mathrm{T}$ sama-sama tidak menghendaki pernikahan tersebut atau sama-sama ingin bercerai mau ada mediasi 2 atau 3 kali kan tetap saja. maka biasanya mediator hanya menginginkan satu kali mediasi, lalu tanda tangan. Biasanya ada 2 tanda tangan, misal tanggal 17 mediasi dan tanggal 24. Soalnya tundaan mediasi minimal pada umumnya seminggu," (Riaya Novia Putri, S.H Advokat PERADI) ${ }^{33}$

Alasan mengapa mediasi perkara cerai kebanyakan dilakukan hanya satu kali diungkapkan oleh beberapa advokat/pengacara sebagai berikut;

1) Ketika di mediasi pertama para pihak kiranya sudah tidak memungkinkan untuk dilakukan mediasi lanjutan, dalam artian salah satu pihak bersikukuh untuk bercerai, maka mediasi cukup dilakukan satu kali. ${ }^{34}$

2) Hal lain yang mempengaruhi mediasi perkara cerai di PA Ponorogo kebanyakan satu kali: ${ }^{35}$ dikehendaki satu kali sudah cukup, Pihak Prinsipiel P (Penggugat/ Pemohon) dan $\mathrm{T}$ (Tergugat/ Termohon) tidak meminta untuk mediasi ulang, dan Mediator bersifat pasif.

3) Kembali ke asas peradilan yakni cepat, sederhana, dan biaya ringan. ${ }^{36}$

31 Ibid.

32 Riaya Novia Putri, Hasil Wawancara, Ponorogo, 26 Januari 2021.

33 Ibid.

34 Endang Misnati, Hasil Wawancara, Ponorogo, 5 Januari 2021.

35Zainal Faizin, Hasil Wawancara, Ponorogo, 12 Januari 2021.

36 Mohammad Padhipta Erfandhiarta, Hasil Wawancara, Ponorogo, 23 Januari 2021. 
Ada beberapa faktor yang mendukung pelaksanaan mediasi secara langsung menurut beberapa pihak diantaranya:

1) Kerjasama dari para pihak secara langsung. ${ }^{37}$

2) Kemampuan mediator, mediator yang handal dalam mengelola konflik dan berkomunikasi sehingga dapat mengupayakan adanya titik temu antar para pihak yang berperkara akan mudah untuk mendorong terjadinya perdamaian. ${ }^{38}$

3) Kalau P dan T sama-sama didampingi kuasa hukum, maka P dan T akan saling mengerti tanpa harus saling menyalahkan \& dapat menghindari konflik yang terlalu panjang, karena kuasa hukum memberikan pemahaman tentang mediasi dan titik temu perdamaian. ${ }^{39}$

4) Kalau $P$ atau $T$ tidak didampingi kuasa hukum, namun pengetahuan Sumber Daya Manusia (SDM) tersebut luas, atau telah memahami informasi yang ia dapat atas relasinya, maka kesadaran hukumnya sudah ada secara ilmiah. ${ }^{40}$

5) $\mathrm{P}$ dan $\mathrm{T}$ memiliki kesadaran hukum secara alamiah (sifat bawaan dan yang ia pelajari). ${ }^{41}$

6) P dan T memiliki iktikad baik/kooperatif ${ }^{42}$

Sedangkan faktor yang menghambat pelaksanaan mediasi secara langsung diantaranya:43

1) Tidak adanya kerja sama dari para pihak untuk menghadiri mediasi. ${ }^{44}$

2) Kurangnya pemahaman dan pengetahuan tentang mediasi oleh para pihak yang berperkara. ${ }^{45}$

3) Jadwal mediasi yang tidak teratur, sehingga mediasi diwakilkan oleh kuasa hukum. Dan kuasa hanya dapat menyampaikan pesan yang diberi oleh pemberi kuasa. ${ }^{46}$

4) P dan T tidak memiliki iktikad baik/ tidak kooperatif.47

\footnotetext{
37 Ahmad Ubaidillah, Hasil Wawancara, Ponorogo, 22 Desember 2020.

38 Pujianto, Hasil Wawancara, Ponorogo, 25 Januari 2021.

39 Zainal Faizin, Hasil Wawancara, Ponorogo, 12 Januari 2021.

40 Ibid.

41 Ibid.

42 Ibid.

43 Ibid.

${ }^{44}$ Ahmad Ubaidillah, Hasil Wawancara, Ponorogo, 22 Desember 2020.

45 Zainal Faizin, Hasil Wawancara, Ponorogo, 12 Januari 2021.

46 Ibid.

47 Ibid.
} 
Berbeda halnya dengan mediasi secara audio visual di PA Ponorogo. Dari 269 perkara cerai yang di mediasi melalui mediator non-hakim PA Ponorogo, hanya 9 perkara cerai yang dimediasi secara audio visual, dengan keberhasilan 0\%.48 Pelaksanaan mediasi secara audio visual dilaksanakan secara online lebih khusus melalui video call kepada salah satu pihak. Ada satu kondisi di mana pada pengajuan perceraian, pihak prinsipiel (P) -karena dia memakai kuasa hukum maka diwakilkan ke kuasa hukumnya, $\mathrm{P}$ tidak bisa hadir karena alasan yang sah sebagaimana dimaksud dalam Pasal 6 Ayat 4 PERMA No.1 Tahun 2016 Tentang Prosedur Mediasi Di Pengadilan yaitu, sakit berdasarkan surat keterangan dari dokter, di bawah pengampuan, berada di luar negeri, tugas Negara/tuntutan profesi/ pekerjaan yang tidak dapat ditinggalkan. ${ }^{49}$

Di PA Ponorogo, pernah diupayakan oleh kebijakan majelis hakim terkait mediasi perkara cerai, bahwa ketika pihak berperkara berada di Luar Negeri, maka majelis hakim dalam sifatnya yang menyarankan, memberi saran kepada Kuasa Hukum untuk berkomunikasi secara langsung dengan prinsipiel (P) agar T juga dapat mendengar secara langsung (komunikasi) terkait alasan 'mengapa kehendak perceraiannya'. Maka dari itu dilaksanakanlah mediasi audio visual dengan pihak P yang di Luar Negeri. ${ }^{50}$ Menurut salah satu kuasa hukum yang pernah beracara mediasi di PA Ponorogo, pelaksanaan mediasi secara audio visual dengan pihak prinsipiel yang berada di Luar Negeri tetap dilakukan dengan pertimbangan bahwa; 51

a) Untuk memastikan bahwa yang mengajukan perkara benar-benar pihak prisipiel yang bersangkutan (bukan rekayasa)

b) Dari penggugat juga mencapai tujuan yakni; Legal standing/ kedudukan hukum, keadilan hukum, dan kemanfaatan hukum

Dalam perkara cerai PA Ponorogo juga pernah melaksanakan mediasi secara audio visual namun pihak P masih berada di Dalam Negeri (NKRI) tapi di Luar Pulau.52 Yang membedakan pelaksanaan mediasi audio visual ketika P/T

48 Data Statistik Perkara Yang Di Mediasi Di Pengadilan Agama Ponorogo Bulan Januari s/d Desember Tahun 2020.

${ }^{49}$ Ahmad Ubaidillah, Hasil Wawancara, Ponorogo, 22 Desember 2020.

50 Ahmad Ubaidillah, Hasil Wawancara, Ponorogo, 22 Desember 2020.

51 Zainal Faizin, Hasil Wawancara, Ponorogo, 12 Januari 2021.

52 Ibid. 
berada di Luar Negeri dan P/T berada di Dalam Negeri yakni adanya surat kuasa istimewa oleh Kuasa Hukum yang dapat menggantikan P/T yang di Luar Negeri untuk mediasi. Sedangkan P/T yang masih di dalam negeri melaksanakan mediasi audio visual demikian. ${ }^{53}$ Terkait pertimbangkan oleh Majelis Hakim dalam mediasi audio visual ketika para pihak di NKRI yakni karena pada sidang pertama $\mathrm{P}$ memang sudah hadir, namun teryata $\mathrm{T}$ tidak hadir. Lalu di sidang kedua ternyata $\mathrm{T}$ hadir, secara otomatis maka perkara ini harus melaksanakan proses mediasi. Tetapi di depan majelis hakim, kuasa hukum menyatakan bahwa pada sidang kedua P sudah tidak bisa izin lagi. Sebab karena; pertama, posisi P berada di luar pulau, kedua, izin dari perusahaan tempat $\mathrm{P}$ bekerja hanya boleh satu kali. Kemudian dari pertimbangan kedua sebab itu, Kuasa Hukum memohon untuk melaksanakan mediasi secara virtual dan hal itu diizinkan oleh majelis hakim dengan pertimbangan bahwa di sidang pertama prinsipiel sudah hadir tetapi pihak $\mathrm{T}$ tidak hadir. Maka dalam proses mediasi dilaksanakan secara virtual melalui video call. ${ }^{54}$ Mediasi audio visual dengan video call biasanya menggunakan aplikasi whatapps, facebook, telegram. ${ }^{55}$ Tetapi dalam kondisi tertuntu, di mana $\mathrm{P}$ berada di luar negeri kemudian dalam kondisi di sana $\mathrm{P}$ sedang bekerja dan tidak memungkinkan untuk video call, maka biasanya cukup dengan mediasi secara audio (telpon -hanya mendengar suara saja tetap dengan aplikasi WhatApps. Namun dalam hal hanya media suara saja, maka sebelum masuk ke pembicaraan lebih lanjut di awal, pihak mediator akan memastikan terlebih dahulu kepada pihak T, 'apakah betul pihak yang diajak komunikasi tersebut adalah pasangannya (suami/istrinya)?' sebab secara umum pasangan tersebut akan mengenali suara suami/istrinya meskipun lama tidak bertemu, namun minimal pasti komunikasi telepon tetap berjalan. ${ }^{56}$

Faktor pendukung mediasi secara audio visual diantaranya sebagai berikut:

1) Menurut Mediator 57

a) Fasilitas yang disediakan oleh Kuasa Hukum.

\footnotetext{
53 Riaya Novia Putri, Hasil Wawancara, Ponorogo, 26 Januari 2021.

54 Ibid.

55 Zainal Faizin, Hasil Wawancara, Ponorogo, 12 Januari 2021.

${ }^{56}$ Ahmad Ubaidillah, Hasil Wawancara, Ponorogo, 22 Desember 2020.

57 Ahmad Ubaidillah, Hasil Wawancara, Ponorogo, 22 Desember 2020.
} 
b) Komunikasi Kuasa Hukum Kepada Kliennya. Hal ini dapat dilihat dari bagaimana Kuasa Hukum mengkomunikasikan dan meyakinkan kepada P agar mau komunikasi dengan lawannya karena terkadang dari awal $\mathrm{P}$ bersikeras memberitahu ke Kuasa Hukumnya bahwa P sudah tidak mau lagi komunikasi dengan lawannya/pasangannya, hal ini juga bisa menjadi penghambat mediasi audio visual.

2) Menurut Kuasa Hukum/Pengacara ${ }^{58}$

a) Fasilitas yang disediakan oleh kuasa hukum memadai untuk melakukan mediasi dalam jaringan (hp, sinyal/buffering, paket data).

b) Jadwal mediasi disepakati.

c) Para pihak memiliki iktikad baik/kooperatif.

d) Para pihak baik yang didampingi oleh kuasa hukum maupun tidak, memiliki pengetahuan/pemahaman terkait mediasi/ kesadaran ilmiah.

e) Para pihak memiliki kesadaran hukum secara alamiah.

3) Menurut para pihak yakni dapat berkomunikasi dengan pihak lawan. ${ }^{59}$

Sedangkan faktor penghambat mediasi secara audio visual yakni;

1) Masalah Teknis atau sinyal60

2) Posisi para pihak dalam keadaan sama-sama emosi. ${ }^{61}$ Ketika para pihak dalam keadaan sama-sama emosi, maka pihak yang ada di lain tempat bisa saja memutus komunikasi/ telepon/ video cal saat mediasi, maka mediator dan pihak yang ada di tempat tidak bisa berbuat banyak. Sebab mediator dan pihak lainnya di tempat itu juga tidak punya nilai tawar untuk menahan komunikasi itu.

3) Menyinkronisasikan jadwal pihak Prinsipiel. ${ }^{62}$

4) Kebijakan majelis hakim pemeriksa perkara yang tidak membolehkan pihak prinsipiel (P) melaksanakan mediasi audio visual (karena majelis hakim mengacu pada hukum acara awal). ${ }^{63}$

58 Zainal Faizin, Hasil Wawancara, Ponorogo, 12 Januari 2021.

59 Pemohon Cerai Talak- Nomor: 2124/Pdt.G/2019/PA.Po (Mediasi Audio Visual di Dalam Negeri), Hasil Wawancara, Ponorogo, 22 Januari 2021.

60 Ahmad Ubaidillah, Hasil Wawancara, Ponorogo, 22 Desember 2020.

61 Ibid.

62 Endang Misnati, Hasil Wawancara, Ponorogo, 5 Januari 2021.

63 Zainal Faizin, Hasil Wawancara, Ponorogo, 12 Januari 2021. 
5) Fasilitas yang disediakan oleh kuasa hukum memadai untuk melakukan mediasi dalam jaringan, namun jaringan pihak klien yang berada di jauh mengalami gangguan. ${ }^{64}$

6) Para pihak memiliki tidak iktikad baik/tidak kooperatif.65

7) Para pihak tidak memiliki pengetahuan/pemahaman terkait mediasi/ kesadaran ilmiah. 66

8) Para pihak tidak memiliki kesadaran hukum secara alamiah. ${ }^{67}$

9) Perbedaan Zona Waktu.

"Pernah klien saya ada di Amerika kan sulit. Kalau kita mau mediasi di sini jam 10 siang, mereka disana udah tenggah malam". ${ }^{68}$

10) Fasilitas dari pengadilan terkait tempat dan alat-alat pendukung teleconfrence belum tersedia. ${ }^{6}$

11) Tidak semua pihak mau mediasi secara audio visual. ${ }^{70}$

Implementasi dari substansi hukum PERMA No.1 Tahun 2016 Tentang Prosedur Mediasi di Pengadilan di PA Ponorogo dapat dipetakan dalam beberapa kategori; ada yang diterapkan, diterapkan tapi tidak maksimal dan ada yang tidak diterapkan dalam hal mediasi secara langsung maupun secara audio visual.

\section{Terlaksana dan diterapkan}

a. Tahapan tugas mediator sebagaimana Pasal 14 PERMA No.1 Tahun 2016 Tentang Prosedur Mediasi di Pengadilan, di PA Ponorogo sudah diterapkan (tahapan proses mediasi; BAB V Pasal 24-32).

b. Mediasi dilakukan tertutup di ruang mediasi PA Ponorogo. Hal ini sesuai dengan Ayat (1) Pasal 5 PERMA No.1 Tahun 2016 Tentang Prosedur Mediasi.

c. Kewajiban para pihak menghadiri mediasi. Hal ini sesuai dengan Ayat (1) Pasal 6 PERMA No.1 Tahun 2016 Tentang Prosedur Mediasi Pelaksanaan mediasi secara audio visual mengacu pada ayat (4) Pasal 6 PERMA No.1 Tahun 2016 Tentang Prosedur Mediasi di Pengadilan

\footnotetext{
64 Ibid.

65 Ibid.

66 Ibid.

67 Ibid.

68 Ibid.

69 Ibid.

70 Riaya Novia Putri, Hasil Wawancara, Ponorogo, 26 Januari 2021.
} 
d. Batas waktu mediasi yakni 30 hari dan dapat diperpanjang. Hal ini sebagaimana Ayat (2) Pasal 24 PERMA No.1 Tahun 2016 Tentang Prosedur Mediasi di Pengadilan.

e. Biaya mediasi dibebankan kepada Penggugat atau tergugat yang tidak beriktikad baik, atau jika keduanya beriktikad baik maka biaya mediasi ditanggung bersama. Hal ini sebagaimana Pasal 22 dan 23 PERMA No.1 Tahun 2016 Tentang Prosedur Mediasi di Pengadilan.

\section{Terlaksana Tapi Tidak Maksimal}

Kewajiban kuasa hukum (Pasal 18 PERMA No.1/2016) mewajibkan para kuasa hukum tersebut membantu dalam hal menyampaikan penjelasan hakim, mendorong para pihak aktif dalam mediasi, membantu para pihak mengidentifikasi kebutuhan, kepentingan dan usulan penyelesaian sengketa selama mediasi, membantu merumusakan rencana kesepakatan perdamaian, menjelaskan kewajiban kuasa hukum kepada kliennya. Akan tetapi dalam praktik mediasi cerai di PA Ponorogo baik melalui tatap muka ataupun virtual/ audio visual kuasa hukum tidak banyak mencampuri urusan klien karena cerai adalah urusan hati ke hati, kecuali dalam aspek yuridisnya.

\section{Tidak Terlaksana}

Dalam hal kewajiban menghadiri mediasi secara langung, di mana dalam Pasal 6 ayat (2) PERMA No.1 Tahun 2016 Tentang Prosedur Mediasi di Pengadilan memuat bahwa kehadiran para pihak melalui audio visual dapat dianggap sebagai kehadiran langsung. Namun dalam prakteknya di PA Ponorogo tidak terlaksana dengan begitu baik. Tidak terlaksana di sini dalam hal ketika pihak prinsipel berada di Luar Negeri dan memakai jasa kuasa hukum yang secara yuridis juga menggunakan surat kuasa istimewa. Pelaksanaan mediasi minimal 2 (dua) kali belum terlaksana sebagaimana Pasal 7 ayat (2). Dalam mediasi perkara cerai (langsung dan audio visual) di PA Ponorogo rata-rata mediasi dilakukan hanya sekali. Namun biasanya untuk laporan mediasi ditanda tangani 2 (dua) kali.

Sedangkan terkait efektivitas hukum implementasi PERMA No.1 Tahun 2016 Tentang Prosedur Mediasi di Pengadilan di PA Ponorogo dilatari beberapa faktor: 


\section{Kualifikasi Mediator}

Terdapat Beberapa hakim yang merangkap sebagai mediator sebanyak 6 (enam) orang, di mana 4 (empat) diantaranya memiliki sertifikat mediator. Sedangkan untuk mediator non hakim hanya 1 (satu) orang. Dengan jumlah perkara yang mencapai 2.280 perkara selama tahun 2020 di PA Ponorogo ${ }^{71}$, tentunya memberikan peran kepada mediator untuk memediasi para pihak yang berperkara. Dualisme fungsi seorang hakim yang juga merangkap menjadi mediator dengan sekian banyaknya perkara yang ditangani oleh PA Ponorogo juga permasalahan-permasalahan lain di luar pengadilan berpengaruh pada psikologi hakim itu sendiri yang menjadikan tidak maksimalnya mediasi.

\section{Fasilitas dan Sarana}

Fasilitas atau sarana yang mendukung mediasi secara langsung yakni adanya ruang mediasi yang merangkap (disekat) menjadi ruang kaukus di PA Ponorogo berukuran sekitar 5 meter x 10 meter. Di dalamnya terdapat sebuah meja dan 6 (enam) kursi untuk mediasi. Terdapat pula 1 (satu) AC/Air Conditioner dan 1 (satu) printer. Dan sebuah meja dengan 3 (tiga) kursi untuk kaukus. Dalam ruang tersebut dapat dilakukan 1 (kali) mediasi. Sedangkan fasilitas yang mendukung untuk mediasi secara audio visual di PA Ponorogo masih dari kuasa hukum seperti handphone dan paket data. Selebihnya dari PA Ponorogo belum ada, seperti belum adanya ruang khusus untuk teleconfence atau fasilitas pendukung mediasi audio visual yang kurang seperti alat yang mendukung teleconfence dan lainnya

Namun untuk keseimbangan jumlah ruang dengan laju perkara yang masuk di PA Ponorogo guna melakukan proses mediasi dengan 1 ruangan sudah cukup. Hal ini ditunjukan dengan pertahun kurang lebih 300 perkara. Jika 300 dibagi 12 bulan, maka 25 perkaa yang di mediasi setiap bulannya. Dan jika waktu hari kerja dibuat rata-rata tiap bulan yakni 20 hari kerja; maka setiap hari hanya 1-2 perkara yag dimediasi, jadi para pihak tidak antri untuk mediasi.

71 Laporan Perkara yang diterima Pengadilan Agama Ponorogo Bulan Januari s/d Desember Tahun 


\section{Kepatuhan Masyarakat}

Dalam hal kepatuhan hukum, mediator sudah mengupayakan pedamaian dalam mediasi cerai baik secara langsung dan secara audio visual dengan bersungguh-sungguh. Dalam hal mediasi secara langsung mediator meminta para pihak terlibat aktif secara langsung ketimbang kuasa hukumnya. Juga dalam hal mediasi audio visual mediator meminta pihak prinsipiel berkomunikasi secara langsung dengan lawannya. Dan dalam hal pihak $\mathrm{P}$ berada di Luar Negeri dan diwakili kuasa hukumnya, mediator tetap meminta untuk dihubungkan melalui jaringan dengan pihak $\mathrm{P}$ agar T dapat mendengar langsung keterangan P perihal keinginan perceraiannya.

Sedangkan kepatuhan hukum kuasa hukum dalam mediasi perkara cerai menahan untuk terlibat pasif dan hanya bergerak dalam aspek yuridis namun dengan tetap melihat posisi dan lawannya. Selain itu dalam hal surat kuasa istimewa kerap kali pihak P berada di Luar Negeri sering kali kuasa hukum tidak melibatkan pihak prinsipiel tersebut untuk mediasi. Padahal Pasal 6 tersebut hanya memberikan opsi bagi yang berhalangan hadir mediasi secara langsung dapat melakukan secara audio visual dengan alasan yang sah; salah satunya berada di Luar Negeri.

Terkait kepatuhan hukum Para pihak dapat dapat dilihat dari kesadaran hukum Para pihak dan adanya iktikad baik/koperatif, para pihak yang beriktikad baik akan berunding dan bekerjasama dalam mengupayakan perdamaian secara sehat di anatara mereka.

\section{Kebudayaan/Budaya Hukum}

Budaya hukum mediasi secara langsung hampir seluruhnya sesuai dengan PERMA No.1 Tahun 2016 Tentang Prosedur Mediasi di Pengadilan kecuali dalam satu hal, yakni kewajiban mediasi yang seharusnya di laksanakan 2 (dua) kali (Pasal 7 ayat (2)), tapi rata-rata hanya dilakukan satu kali dengan ditandatangani 2 kali. Selain itu dalam hal pihak P berada di Luar Negeri seharusnya $\mathrm{P}$ dengan tetap diwajibkan terlibat aktif melaksanakan mediasi secara audio visual sebagai opsi, bukan dengan sah-sah saja mempasrahkan kepada kuasa hukumnya untuk mewakilinya dengan dalih adanya surat kuasa istimewa. Hal ini harusnya sama seperti pelaksanaan 
mediasi secara audio visual ketika pihak prinsipiel berada di Dalam Negeri. Pelunakan PERMA No.1 Tahun 2016 Tentang Prosedur Mediasi di Pengadilan seharusnya hanya sebtas opsi bagi para pihak untuk memilih model mediasinya, bukan menghapuskan kewajibannya dan mengkuasakan kepada kuasa hukumnya secara menyeluruh.

\section{PENUTUP}

Dari hasil penelitian yang peneliti lakukan, adapun kesimpulan yakni efektivitas antara mediasi secara langsung dan mediasi secara audio visual dalam perkarai cerai di PA Ponorogo keduanya sama-sama masih kurang efektif. Namun dilihat dari faktor substansi hukum, kualifikasi mediator, fasilitas, kepatuhan hukum, dan budaya hukum ketidaksesuaian dan kekurangan mediasi audio visual dalam PERMA No.1 Tahun 2016 Tentang Prosedur Mediasi di Pengadilan dan faktor pendukung efektivitas hukum lebih mendominasi ketimbang mediasi secara langsung. Maka antara keduanya, mediasi secara langsung lebih memenuhi faktor pendukung efektivitas hukum ketimbang mediasi secara audio visual. Dapat dikatakan bahwa mediasi secara langsung dalam perkara cerai di PA Ponorogo lebih efektif daripada mediasi secara audio visual.

Dalam Perkara Cerai di PA Ponorogo, faktor pendukung mediasi secara langsung adalah; kemampuan mediator dan kuasa hukum yang handal, kesadaran hukum, iktikad baik, dan pengetahuan hukum para pihak. Sedangkan faktor penghambat mediasi secara langsung adalah kurangnya kemampuan mediator dalam mengolah konflik, tidak ada iktikad baik para pihak/kuasa hukum,dan jadwal mediasi yang tidak teratur. Kemudian faktor pendukung mediasi secara audio visual yakni; fasilitas yang memadai baik dari para pihak, kuasa hukum ataupun PA, komunikasi kuasa hukum pada kliennya yang informatif dan edukatif, iktikad baik dan pengetahuan hukum para pihak serta jadwal yang disepakati, sedangkan faktor penghambat mediasi secara audio visual yakni kebijakan majelis hakim, fasilitas yang kurang memadai, perbedaan zona waktu, dan emosional para pihak.

Untuk memaksimalkan implementasi regulasi tersebut, PA Ponorogo perlu menambah mediator non hakim untuk membantu meringankan hakim dalam menjalankan proses mediasi agar mediasi dapat lebih maksimal. PA Ponorogo 
bersama dengan Mahkamah Agung juga perlu mengadakan kembali pelatihan, pengawasan dan evaluasi lanjutan terkait peran mediator dan Penegakan PERMA No.1 Tahun 2016 Tentang Prosedur Mediasi di Pengadilan, dalam memediasi para pihak agar keberhasilan mediasi meningkat. Tak lupa juga sangat diperlukan adanya fasilitas pendukung mediasi audio visual juga ruang mediasi khusus teleconfrence di PA Ponorogo.

\section{DAFTAR PUSTAKA}

Aziz, Muhammad Faiz, dan Muhamamd Arif Hidayah. "Perlunya Pengaturan Khusus Online Dispute Resolution (Odr) Di Indonesia Untuk Fasilitasi Penyelesaian Sengketa E-Commerce." Jurnal Rechts Vinding: Media Pembinaan Hukum Nasional 9, no. 2 (27 Agustus 2020): 275. https://doi.org/10.33331/rechtsvinding.v9i2.449.

A. Syukur, Fatahillah. Mediasi Yudisial Di Indonesia. Bandung: Mandar Maju, 2012.

Chanafi, Muhammad. "Disusun dan Diajukan Untuk Melengkapi Tugas-tugas dan Syarat-syarat Guna Mencapai Derajat Sarjana Hukum pada Fakultas Hukum Universitas Muhammadiyah Surakarta," t.t., 12.

Data Statistik Perkara Yang Di Mediasi Di Pengadilan Agama Ponorogo Bulan Januari s/d Desember Tahun 2020.

Faruq, Ubaid Al. "Metode Penelitian Hukum," t.t., 244.

Herawati, Netty. "Implikasi Mediasi Dalam Perkara Perdata Di Pengadilan Negeri Terhadap Asas Peradilan Sederhana, Cepat, Dan Biaya Ringan." Perspektif 16, no. 4 (27 September 2011): 227. https://doi.org/10.30742/perspektif.v16i4.85.

Laporan Perkara yang diputus Pengadilan Agama Ponorogo Bulan Januari s/d Desember Tahun 2020

Laporan Perkara yang diterima Pengadilan Agama Ponorogo Bulan Januari s/d Desember Tahun 2020

Mas, Tsaniah Rochmat Kamardeka. "Diajukan Kepada Fakultas Syariah Institut Agama Islam Negeri (IAIN) Surakarta Untuk Memenuhi Sebagian Persyaratan Guna Memperoleh Gelar Sarjana Hukum," no. 1 (2016): 127.

Muawwanah, Rohana. "Realitas Gugat Cerai TKW (Asia Timur) di Kabupaten Ponorogo: Sebuah Tinjauan Hukum Islam." Edugama: Jurnal Kependidikan dan Sosial Keagamaan 5, no. 2 (1 Desember 2019): 154-82. https://doi.org/10.32923/edugama.v5i2.975.

Nafisah, Putri. Implemetasi Mediasi Melalui Sarana Audio Visual Berdasarkan PERMA No. 1 Tahun 2016 Pasal 5 ayat (3), Skripsi. Malang: Universitas Islam Negeri Maulana Malik Ibrahim, 2018.

Nugroho, Susanti Adi. Mediasi Sebagai Alternatif Penyelesaian Sengketa,. Jakarta: PT Telaga Ilmu Indonesia, 2009. 
Safudin, Endrik. Alternatif penyelesaian sengketa dan arbitrase. Cetakan pertama. Malang: Intrans Publishing, 2018.

Saifullah, Muhammad. Mediasi Dalam Tinjauan Hukum Islam dan Hukum Positif di Indonesia. Semarang: Walisongo Press, 2009.

Saifullah, Muhammad. "Efektivitas Mediasi Dalam Penyelesaian Perkara Perceraian Di Pengadilan Agama Jawa Tengah." Al-Ahkam 25, no. 2 (24 Oktober 2015): 181. https://doi.org/10.21580/ahkam.2015.25.2.601.

Salamah, Yayah Yarotul. "Urgensi Mediasi dalam Perkara Perceraian di Pengadilan Agama." AHKAM : Jurnal Ilmu Syariah 13, no. 1 (1 Februari 2013). https://doi.org/10.15408/ajis.v13i1.953.

Soekanto , Soerjono. Penegakan Hukum. Bandung: Bina cipta, 1983.

Soekanto, Soerjono. Faktor-Faktor Yang Mempengaruhi Penegakan Hukum, Depok: RajaGrafindo Persada, 2018.

Syahrizal, Agustina Arida, dan Luthfi Aunie. Mediasi dalam perspektif hukum syariah, hukum adat \& hukum nasional. Cet. 1. Jakarta: Kerja sama Canadian International Development Agency ... [et al.], 2009.

Wirhanuddin. "Deskripsi Tentang Mediasi Di Pengadilan Tinggi Makasar", Al-Fikr, Vol. 20 No.2. 2015. 279-303.

(C) 2021 by the authors. Submitted for possible open access publication under the terms and conditions of the Creative Commons Attribution-NonCommercial 4.0 International License (CC BY NC) license (https:// creativecommons.org/licenses/by$\mathrm{nc} / 4.0 /)$. 